\title{
PERANAN EMOTIONAL SPIRITUAL QUOTIENT (ESQ) DALAM DOING THEOLOGY
}

\author{
Obet Nego, M.Th \\ Debby Christ Mondolu, ST
}

\begin{abstract}
Abstrak
Dalam berteologi, Allah adalah sumber teologi, pokok teologi dan tujuan teologi. Dalam hal ini, Allah membuat manusia mempelajari-Nya di dalam Alkitab (Sola Scriptura), dan Roh Kudus yang menyingkapkan kebenaran-Nya sehingga menimbulkan iman di dalam diri umat-Nya (Sola Fide) kepada Allah dan kebenaranNya yang final, yaitu Tuhan Yesus Kristus saja (Sola Christo). Akhirnya, memimpin umat-Nya kepada diri-Nya sendiri dan demi kemuliaan nama Allah (Soli Deo Gloria). Dalam karya tulis memandang prinsip-prinsip dalam konsep Emotional Spiritual Quotient (ESQ) penting untuk diintegrasikan ke dalam doing theology atau berteologi. Dalam upaya mensinergiskan kecerdasan intelektual, emosi dan spiritual dalam berteologi yang teosentris, di mana kecerdasan spiritual (SQ) menjadi pusat kecerdasan.
\end{abstract}

\section{A. Latar Belakang Penulisan}

Pada masa kini, teologi-teologi yang antroposentris telah menjangkiti atmosfer doing theology. Mulai dari teologi yang didirikan di atas keyakinan pada keunggulan rasionalitas, fokus terhadap pengalaman pribadi yang emosional (emotional experience) hingga pengalaman transformasi spiritual-psikologi pribadi. Akibatnya, pola-pola berteologi tersebut telah mengesampingkan nilai-nilai spiritualitas yang sejati. Hal tersebut, tidak bisa terlepas dari rentetan sejarah pemikiran theologia.

Sebelum era Renaissance ${ }^{1}$, teologi memegang wibawa tertinggi sebagai Queen of the sciences. ${ }^{2}$ Namun, akibat perpaduan filsafat Plato dan Humanisme telah melahirkan kebangkitan dari kebebasan individu, yaitu Renaissance pada abad XIV, sehingga masa ini memaklumkan bahwa manusia sendiri adalah kaidah atau ukuran

${ }^{1}$ Istilah "Renaissance" adalah kata Perancis yang berarti "kelahiran kembali" dari kebudayaan dan kesenian kuno. Kata ini dipakai untuk memaksudkan munculnya kesadaran baru terhadap keindahan dunia dan manusia. H. Berkhof, I.H. Enklaar, Sejarah Gereja, (Jakarta: BPK Gunung Mulia, 1999), h.99

${ }^{2}$ E. Gerrit Singgih, Mengantisipasi Masa Depan: Berteologi dalam Konteks di Awal Milenium III, (Jakarta: BPK Gunung Mulia, 2005), h.11 
dari segala sesuatu, bukan lagi gereja ataupun teologi. ${ }^{3}$ Pengaruh Renaissance makin lama makin mempengaruhi berbagai aspek kehidupan, sehingga bertambah banyak orang secara khusus para cendikiawan mulai melepaskan diri dari kuasa Firman Tuhan. Begitu juga dengan ilmu pengetahuan dan kebudayaan mulai memisahkan diri dari ajaran-ajaran gereja. ${ }^{4}$ Dalam perkembangannya lebih lanjut, Renaissance membuahkan filsafat Rasionalisme ${ }^{5}$ yang berkembang pada abad XVII. Rasionalisme sendiri berpijak pada diktum Rene Descrates sebagai Bapak Rasionalisme (15961650) yang mencanangkan cogito ergo sum. ${ }^{6}$

Berbeda dengan teologi pengalaman ${ }^{7}$, teologi ini justru berorientasi kepada pengalaman yang melibatkan emosi pribadi. Warna teologi pengalaman dapat terlihat dalam gerakan Pentakostalisme atau kaum Kharismatik. Gerakan ini merupakan "pakaian baru" dari teologi Schleiermacher dan Barth, sekalipun teologi kaum Kharismatik tidak muncul sebagai hasil dari mempelajari teologi kedua teolog tersebut. Namun, teologi kaum Kharismatik maupun teologi Schleiermacher dan Barth sama-sama dibangun melalui atau berdasarkan pengalaman pribadi, di mana teologi kehilangan obyektivitasnya. Gerakan yang lahir pada abad XX ini, menjadikan peranan Roh Kudus lebih besar dalam kehidupan mereka dibandingkan dengan Yesus Kristus. ${ }^{8}$ Pengalaman khusus dan kesaksian-kesaksian juga mengambil tempat yang lebih tinggi dari Alkitab sebagai Firman Allah. Bahkan, melalui pengalaman-pengalaman khusus tersebut, gerakan ini bisa menerima "wahyu baru" yang lebih dinamis, dibandingkan dengan Alkitab sebagai penyataan tertulis dari Allah yang dianggap beku dan tidak hidup lagi. ${ }^{9}$

Dari runtut pemikiran teologi dalam sejarah kekristenan tersebut, dapat terlihat adanya ketegangan antara "teologi intelektualis" dan "teologi pengalaman." Yang pertama, menekankan pada pemikiran filosofis kebenaran-kebenaran Kristen yang dideduksi dari kebenaran-kebenaran Alkitab. Yang kedua, lebih menekankan pada pengalaman transformatif melalui suatu perjumpaan (encounter) dengan yang Ilahi. ${ }^{10}$

${ }^{3}$ H. Berkhof, I.H. Enklaar, Sejarah..., h.99

${ }^{4}$ Ibid, h. 256

${ }^{5}$ Rasionalisme adalah paham yang beranggapan bahwa segala sesuatu dapat dimengerti melalui akal budi. Akal budi menjadi ukuran segala sesuatu. Dari abad XVI yang dikenal abad reformasi ke abad XVII yang dikenal dengan abad Rasionalisme, telah terjadi perubahan perhatian yang besar, yaitu perhatian manusia beralih dari Allah kepada manusia. Stevri Indra Lumintang, Theologia Abu..., h.165

${ }^{6}$ Hendra Gunawan, "Gereja, Teologi, dan Pertumbuhan Rohani," Jurnal Amanat Agung vol 2 no 1, (April 2006), 151

${ }^{7}$ Wilfred J. Samuel, Kristen Kharismatik, (Jakarta: BPK Gunung Mulia, 2007), 76

${ }^{8}$ Hans Maris, Gerakan Karismatik dan Gereja Kita, (Jakarta: Momentum, 2004), 28

${ }_{9}$ Ibid, h.34

${ }^{10}$ Hendra Gunawan, “Gereja, Teologi dan Perkembangan Rohani,” Jurnal Amanat Agung..., 
Dalam aktivitasnya, terlihat dalam kegiatan beribadah yang penuh respon emosional, seakan-akan menjadikan gerakan ini sebagai jawaban akan kebutuhan spiritualitas gereja tradisional, yang selama ini mengalami kekakuan. ${ }^{11}$ Searah dengan hal ini, R.C Sproul memberikan penjelasan mengenai kehidupan rohani yang berorentasi pada perasaan atau emosi tersebut:

Orang Kristen "perasaan" hidupnya dikendalikan oleh perasaannya, bukan oleh pengertiannya tentang Firman Allah. Orang-orang Kristen perasaan tidak dapat digerakkan untuk berbakti, berdoa atau belajar, kalau ia tidak merasa tergerak secara alami untuk melakukannya. Kehidupan kekristenannya baru efektif kalau perasaannya kuat. Ketika ia merasakan euforia (rasa bahagia tanpa sebab yang jelas) secara spiritual, ia menjadi badai aktivitas ilahi; ketika ia sedang merasakan depresi, maka kerohaniannya juga loyo. Ia selalu mencari-cari pengalaman-pengalaman rohani yang baru dan segar serta menggunakannya sebagai penentu Firman Allah untuk menentukan Firman Allah. Perasaanperasaan batinnya menjadi ujian kebenaran yang paling utama. ${ }^{12}$

Dalam hal ini, penganut teologi pengalaman atau teologi yang berorientasi pada perasaan atau emosi tidak merasa perlu belajar Firman Allah, sebab mereka mengira bahwa mereka sudah mengenal kehendak Allah melalui perasaan mereka.

Teolog yang tidak cerdas secara emosi maupun spiritual akan mudah sekali jatuh dalam praktik berteologi yang salah. Di sinilah peranan Emotional Spiritual Quotient (ESQ) dalam doing theology agar setiap teolog memiliki kapasitas tersebut, guna menghasilkan orthodoxi, orthopathi dan orthopraxi dalam berteologi.

Dari pemaparan berbagai fenomena doing theology atau berteologi tersebut, mulai dari runtut sejarahnya hingga kenyataan berteologi pada masa kini, sepatutnyalah dibutuhkan teolog yang memiliki kecerdasan seimbang dalam berteologi. Ketika rasio dan emosi semakin seimbang, maka teolog tersebut semakin cerdas dalam berteologi. R.C Sproul menjelaskan hubungan kedua aspek ini (rasio dan emosi) lebih lanjut:

Alkitab ditujukan kepada intelek tanpa sekaligus memeluk semangat intelektualisme. Kehidupan Kristen tidak dimaksudkan untuk menjadi kehidupan yang semata-mata teoritis atau rasionalisme yang dingin. Kehidupan Kristen harus menjadi kehidupan yang bersemangat. Perasaan-perasaan sukacita, kasih dan pujian yang kuat berulang-ulang diperintahkan. Namun, perasaan-perasaan yang yang kuat itu merupakan respon terhadap apa yang kita pahami dengan pikiran kita sebagai sesuatu yang benar. ${ }^{13}$

${ }^{11}$ Christian de Jonge, Pembimbing ke Dalam Sejarah Gereja, (Jakarta: BPK Gunung Mulia, 1993), 79

${ }^{12}$ R.C. Sproul, Mengenali Alkitab, (Malang: Literatur SAAT, 2001), 19-20

${ }_{13}$ R.C. Sproul, Mengenali..., 21 
Dengan demikian, penulis memandang prinsip-prinsip dalam konsep Emotional Spiritual Quotient (ESQ) penting untuk diintegrasikan ke dalam doing theology atau berteologi. Dalam upaya mensinergiskan kecerdasan intelektual, emosi dan spiritual dalam berteologi yang teosentris, di mana kecerdasan spiritual $(S Q)$ menjadi pusat kecerdasan. Seperti pernyataan Steven R. Covey mengenai Emotional Spiritual Quotient (ESQ) yang dikutip oleh Ary Ginanjar Agustian: "Spiritual intelligence is the central and most fundamental of all the other three intelligence." 14

Lukas 10:27 menegaskan: "Kasihilah Tuhan Allahmu, dengan segenap hatimu, dan dengan segenap kekuatanmu dan dengan segenap akal budimu. ..." Karena itu, seorang teolog membutuhkan kecerdasan intelektual $(I Q)$ dan emosi $(E Q)$ yang seimbang dan berpusat pada kecerdasan spiritual $(S Q)$. Hal inilah yang menstimulasi penulis untuk menuliskannya dalam karya tulis yang berjudul: Pentingnya Emotional Spiritual Quotient (ESQ) dalam Doing Theology di Indonesia.

Dengan demikian dalam berteologi, Allah adalah sumber teologi, pokok teologi dan tujuan teologi. Dalam hal ini, Allah membuat manusia mempelajari-Nya di dalam Alkitab (Sola Scriptura), dan Roh Kudus yang menyingkapkan kebenaran-Nya sehingga menimbulkan iman di dalam diri umat-Nya (Sola Fide) kepada Allah dan kebenaran-Nya yang final, yaitu Tuhan Yesus Kristus saja (Sola Christo). Akhirnya, memimpin umat-Nya kepada diri-Nya sendiri dan demi kemuliaan nama Allah (Soli Deo Gloria).

\section{A. Emotional Quotient (EQ) dalam Doing Theology}

Keterlibatan perasaan atau emosi tidak bisa dilepaskan dalam kegiatan berteologi. Namun, sebagai salah satu bagian yang inheren dari jiwa manusia, emosi yang benar harus dimiliki dalam merespon penyataan Allah. Dengan demikian, upaya mengintegrasikan prinsip-prinsip Emotional Quotient $(E Q)$ ke dalam doing theology diharapkan mengoptimalkan kompetensi intrapersonal maupun interpersonal teolog dalam berteologi.

\section{Kesadaran Diri (Self-Awareness) dalam Doing Theology}

Emosi merupakan tanggapan yang kompleks, biasanya sangat subyektif dan melibatkan perubahan-perubahan fisiologis sebagai persiapan tindakan. ${ }^{15}$ Karena kompleksitasnya, emosi-emosi tidak mudah untuk dijelaskan, sehingga kadang-

${ }^{14}$ Ary Ginanjar Agustian, Rahasia Sukses Membangun Kecerdasan Emosi dan Spiritual (ESQ) Emotional Spiritual Quotient Berdasarkan 6 Rukun Iman dan 5 Rukun Islam, (Jakarta: Penerbit Arga, 2005), 9

15 Webster's II New College Dictionary, (Boston/New York: Houghton Mifflin Company, 1995), s.v. "emosi”, dikutip oleh Joyce Meyer, Mengelola Emosi Anda, (Batam: Gospel Press, 2005), 9 
kadang menjadi sulit dikelola. Namun bagaimanapun, dalam meresponi kehendak Allah, emosi mengambil peranan di dalamnya. Berkenaan dengan hal ini, Joyce Meyer dalam bukunya "Mengelola Emosi Anda" menjelaskan:

. . . ada saat-saat di mana Roh Kudus memimpin kita untuk melakukan sesuatu dan emosi-emosi kita terlibat, sehingga kita bergairah untuk melakukannya. Dukungan emosional membantu kita merasakan bahwa Allah benar-benar ingin agar kita melakukan suatu hal. Kita mengasumsikan dukungan emosional sebagai penegasan kehendak Allah. ${ }^{16}$

Tetapi yang harus diwaspadai dalam hal ini adalah emosionalisme atau kecenderungan untuk mengandalkan atau menempatkan bagian yang terlalu besar pada emosi, sehingga emosi acapkali dijadikan standart dalam mengetahui kehendak Allah. Karena itu, tergerak secara emosional tidak selalu berarti dipimpin oleh Roh Kudus. Joyce Meyer kembali menjelaskan:

... pada kesempatan lain, Allah akan menggerakkan kita untuk melakukan suatu hal, tetapi emosi-emosi kita tidak ingin berurusan dengan apa yang Allah nyatakan dan perintahkan untuk kita lakukan. Emosi itu sama sekali tidak memberi dukungan. Pada saat-saat seperti itu, sulit bagi kita untuk mentaati Allah. Kita sangat tergantung pada dukungan emosional. Jika kita kurang memahami sifat dari emosi atau kurangnya pengendaliannya, setan dapat memanfaatkannya untuk menjauhkan kita dari kehendak Allah. Saya sangat percaya bahwa tidak seorang pun akan hidup di dalam kehendak Allah dan akhirnya hidup dalam kemenangan, jika hanya menuruti emosi-emosinya. ${ }^{17}$

Bagi seorang teolog, memahami hal ini sangatlah penting. Kesadaran diri (self awareness) tentunya dalam bentuk kesadaran emosi akan mampu mengendalikan perasaan-perasaan yang berlebihan, sehingga tanggap terhadap setiap emosi. Peter wongso dalam bukunya "Hamba Tuhan dan Jemaat Kristus yang Melintasi Zaman" melihat gejala tersebut:

Apabila teolog hanya menekankan emosi, maka ia akan terlalu mudah secara membabi buta mengikuti gerakan baru dari penafsiran Alkitab, dan juga pengalaman-pengalaman aneh dari orang lain. Di tengah jemaat Tuhan dewasa ini, tidak jarang kita mendengar ungkapan yang cenderung pada penekanan emosi seperti: "aku merasakan penyertaan Allah," "aku merasakan Allah telah jauh meninggalkan aku," "aku merasakan Roh Kudus memenuhiku," "aku merasakan penyertaan Allah begitu kuat" dan sebagainya. Apakah tepat menilai penyertaan Allah, kasih Allah, kepenuhan Roh Kudus itu dengan perasaan

\footnotetext{
16 Joyce Meyer, Mengelola..., 9

${ }^{17}$ Ibid., 9-10
} 
pribadi yang subyektif semacam itu? Apakah ungkapan tersebut dapat dipertanggungjawabkan? ${ }^{18}$

Intinya, memakai perasaan sebagai dasar penentuan kebenaran rohani tidak dapat dipertanggungjawabkan. Jika tidak, "perasaan" itu akan menimbulkan masalah yang menyebabkan seorang teolog keluar dari kehendak Allah.

\section{a. Intuisi dan Suara Hati}

Intuisi adalah perasaan langsung dari indera roh manusia, karena indera ini timbul secara langsung, tanpa perantara, tanpa alasan, dan tanpa melalui prosedur apapun. ${ }^{19}$ Melalui intuisi inilah roh manusia menyatakan kehendaknya. Lebih rinci, Watchman Nee menjelaskan:

Roh Kudus menyatakan kehendak-Nya melalui perasaan-perasaan halus dalam roh kita. Ia tidak langsung bekerja dalam pikiran kita dan mendadak mengingatkan kita pada sesuatu. Semua pekerjaan Roh Kudus dilakukan dalam lubuk roh kita. Karena itu, jika kita ingin mengerti maksud Roh Kudus, haruslah kita menurut petunjuk intuisi dalam roh kita. Petunjuk-petunjuk atau ajaran-ajaran intuisi barulah menunjukkan maksud dan kehendak Roh Kudus. ${ }^{20}$

Dengan demikian, intuisi akan memampukan seorang teolog untuk membedakan mana yang sebenarnya berasal dari Roh Kudus, mana yang berasal dari diri sendiri, dan mana yang berasal dari iblis.

Selain intuisi, Suara hati juga merupakan bagian dari fungsi roh. ${ }^{21}$ Kata "suara hati" berasal dari bahasa Latin "conscientia" yang berarti, "mengetahui bersama" atau "mengetahui dengan." Secara tradisional, suara hati dipahami dalam pengertian psikologis, yaitu "kesadaran," dan dalam pengertian moral, yaitu "kesadaran tentang yang benar dan yang salah." 22 Hati nurani berfungsi menunjukkan kesalahan, menegur dan menggelisahkan hati jika melakukan sesuatu yang tidak memuliakan Allah. Bersama dengan intuisi, hati nurani akan bangkit untuk menentang keinginankeinginan yang dibenci oleh Roh Kudus, dan akan menghasilkan ketidaktentraman dalam hati. ${ }^{23}$

${ }^{18}$ Peter Wongso, Hamba Tuhan dan Jemaat Kristus yang Melintasi Zaman, (Malang: Literatur SAAT, 2002), 183

${ }^{19}$ Watchman Nee, Manusia Rohani 2, (Surabaya: Yayasan Perpustakaan Injil Indonesia, 1999), 438

${ }^{20}$ Ibid, 368-369

${ }^{21}$ Watchman Nee, Manusia..., 432

${ }^{22}$ Dennis J. Billy, James F. Keating, Suara Hati dan Doa: Belajar Terbuka pada Kebenaran, (Yogyakarta: Kanisius, 2008), 21

${ }^{23}$ Watchman Nee, Manusia..., 496-497 
Keterlibatan intuisi dan suara hati dalam mengontrol diri dalam arah kesadaran diri sangatlah penting. Dengan lebih peka mengikuti intuisi dan suara hati yang telah diterangi oleh Roh Kudus, maka seorang teolog akan lebih terampil lagi dalam memanage emosinya dalam berteologi.

\section{b. Kepercayaan Diri}

Satu-satunya mahluk yang dapat menghadap diri, menilai diri dan menghakimi diri adalah manusia. Itulah sebabnya, di dalam diri dapat berdialog dengan diri sendiri. Dengan demikian, diri sendiri dapat menolong diri sendiri, membakar semangat sendiri dan dapat membunuh diri sendiri. ${ }^{24}$

Di dalam keberadaan manusia ini, iblis selalu berusaha memberikan racun, sehingga mengakibatkan dua hal, yaitu penilaian diri selalu rendah, sehingga mengakibatkan sifat minder (rendah diri) akibat dari sifat inferiority complex, dan penilaian diri terlalu tinggi, sehingga mengakibatkan superiority complex. ${ }^{25}$ Orang yang menilai diri terlalu rendah akan mengubur semua bakat yang Tuhan berikan padanya, lalu menjadikannya sebagai orang yang tidak berguna. Sedangkan orang yang menilai dirinya sendiri terlalu tinggi, akan menjadikanya memiliki perasaan kesombongan rohani. Biasanya, hal ini disebabkan oleh perasaan yang "unggul secara rohani," oleh karena pengkultusan karunia-karunia rohani yang dimiliki, ${ }^{26}$ atau kesombongan dalam memutlakkan rumusan-rumusan dogmatis tertentu, akibatnya pikiran atau pandangan orang lain diremehkan. ${ }^{27}$

Keyakinan (confidence) sangat dibutuhkan manusia. Tetapi, keyakinan ini harus didasarkan pada pengevaluasian diri yang wajar ( $\mathrm{Rm} .12: 3$ ), yaitu sesuai dengan iman yang diberikan. ${ }^{28}$ Seorang teolog harus melihat diri sendiri di posisi yang tepat, tidak terlalu tinggi, tetapi juga tidak terlalu rendah.

\section{Pengaturan Diri (Managing Emotion) dalam Doing Theology}

Prinsip kecerdasan emosi ini, yaitu pengaturan diri (managing emotion), atau penguasaan diri merupakan buah dari pekerjaan Roh Kudus dalam diri seseorang.

${ }^{24}$ Stephen Tong, Roh Kudus, Suara Hati Nurani dan Setan, (Jakarta: Momentum, 1997), 58

${ }^{25}$ Ibid, 59

${ }^{26}$ Wilfred J. Samuel, Kristen Kharismatik: Refleksi atas Berbagai Kecenderungan Pasca Kharismatik, (Jakarta: BPK Gunung Mulia, 2007), 51

${ }^{27}$ Stevri Indra Lumintang, Theologia dan Misiologia Reformed, (Batu: Departemen Literatur PPII, 2006), 39

${ }^{28}$ Stephen Tong, Roh Kudus..., 59 
Roh Kudus yang tinggal, akan memampukan seseorang untuk mengendalikan dirinya. Mungkin lebih tepat, dikendalikan oleh Roh Kudus, bukan oleh diri sendiri. ${ }^{29}$

Dengan pengertian lain, seorang teolog harus bersedia mempersembahkan anggota tubuhnya kepada Allah untuk dipakai-Nya guna melakukan kehendak-Nya (Rm. 8:9). Seperti halnya Rasul Paulus menyadari, ia harus berdisiplin dalam menguasai diri, apabila ia mau menjadi teladan yang konsekuen dan hamba Kristus yang setia (1Kor. 9:27). Prinsip kecerdasan emosi ini mutlak untuk dimiliki oleh seorang teolog, yang telah memberikan hidupnya untuk Tuhan, di mana prinsip ini meliputi integritas dan adaptabilitas.

\section{a. Integritas}

Membuat dan menepati janji pada diri sendiri, sesama manusia, dan Tuhan merupakan wujud dari tindakan penuh integritas. ${ }^{30}$ Menjaga integritas merupakan pergumulan setiap orang percaya yang mau serius menjadi murid-Nya. Rasul Paulus sendiri memahami benar bahwa integritas adalah suatu keharusan bagi dirinya sebagai pembawa pesan Tuhan. Rahasia kebenaran-Nya hanya akan diberikan kepada orang-orang yang benar-benar tunduk dan taat mengikuti aturan main-Nya (1Kor. $9: 27)^{31}$

Hal ini menunjukkan bahwa, seorang teolog juga dituntut untuk memiliki integritas dalam membuktikan integritas imannya. Yohanes Bambang Mulyono menjelaskan hal tersebut:

Ini berarti hanya orang yang memiliki integritas saja yang akan dipilih oleh Allah dalam karyaNya. Allah tidak akan pernah memilih dan memakai orang yang berwajah mendua (munafik) untuk melaksanakan karya keselamatanNya. Demikian pula Allah tidak akan memakai kita walaupun kita seorang Kristen manakala kehidupan kita penuh dengan kemunafikan, cacat secara moral dan jauh dari sikap integritas. Predikat kekristenan kita tidak secara otomatis mengubah watak, pola pikir dan kepribadian kita. Karena itu setiap orang Kristen harus mampu membuktikan integritas iman di tengah-tengah berbagai kesulitan dan tekanan hidup ini. ${ }^{32}$

Karena itu, kunci integritas Kristen bukan terletak pada kekuatan manusia, tetapi pada kekuatan Roh Kudus yang mampu terus memperbarui kehidupan pribadi

${ }^{29}$ Roger Roberts, Hidup Suci: Panggilan Bagi Setiap Orang Kristen, (Bandung: Lembaga Literatur Baptis, 2000), 117

${ }^{30}$ Martin Wijongko, "Integritas: Menepati Komitmen," http://www.smakristencilacap.com, On Line 17 November 2009

31 Andi Andreas, "Menjaga Integritas," http://www.akupercaya.com/forums/pengajaranalkitab/6372- html, On Line 17 November 2009

${ }^{32}$ Yohanes Bambang Mulyono, "Integritas Iman dan Tindakan," http://www.gki.or.id/doc.php?doctype, On Line 17 Nopember 2009 
seseorang. Namun yang penting untuk dicermati bahwa, manifestasi karunia-karunia roh juga tidak bisa menjadi tolok ukurnya (Mat. 7:22), kembali Yohanes Bambang Mulyono menjelaskan:

Sebab orang-orang yang tidak memiliki integritas diri ternyata dapat melakukan berbagai perbuatan ajaib seperti: bernubuat, mengusir setan dan mengadakan banyak mukjizat demi nama Tuhan. Walaupun hidup mereka tidak benar, ternyata Tuhan dalam kasus-kasus tertentu berkenan memberikan karunia tertentu. Karena itu pemberian karunia roh tersebut bukan suatu jaminan bahwa kehidupan mereka telah berkenan di hadapan Tuhan. Karunia-karunia roh dalam kehidupan umat percaya tidak ada hubungannya dengan integritas dan kualitas diri. Jadi karunia-karunia roh tidak dapat dijadikan tolok ukur untuk mengetahui seberapa tinggi integritas yang dimiliki oleh orang yang percaya. Ini berarti pula seseorang yang memiliki integritas juga tidak senantiasa harus memiliki berbagai karunia roh seperti mampu bernubuat, mengusir setan dan mengadakan banyak mukjizat. Justru mereka yang hanya mengandalkan kepada karunia-karunia roh namun mereka mengabaikan integritas dirinya, hanya akan menjadi batu sandungan bagi orang lain. ${ }^{33}$

Iman yang berintegritas, haruslah sungguh-sungguh memahami apa yang ia yakini dengan keterbukaan dan dengan seluruh kemampuan berpikir kritis untuk "menguji" seluruh kebenaran suatu ajaran. ${ }^{34}$ Dengan kata lain, seseorang yang menghayati integritas dirinya perlu senantiasa waspada karena spiritualitas yang dimiliki masih dapat dibelokkan atau disesatkan oleh kuasa dunia ini. Karena itu, integritas diri perlu terus-menerus ditanamkan sedalam-dalamnya dengan sikap kasih dan pengajaran Firman Tuhan, berupa semangat untuk menyelidiki Alkitab secara pribadi perlu terus menerus dikembangkan dalam kehidupan setiap hari. ${ }^{35}$

Secara sederhana integritas dapat dikatakan sebagai, "Satunya kata dan perbuatan." Hidup yang tulus dengan Tuhan, pastilah akan melahirkan integritas hidup yang sejati. Sebagai kompetensi intrapersonal, integritas akan menghasilkan keselarasan dan konsistensi terhadap seluruh aspek dalam kepribadian seorang teolog.

\section{b. Adaptabilitas}

Pada awalnya, pendidikan teologi tradisional menempatkan Alkitab, praktik "lectio divina," penelusuran pemikiran Bapa Gereja dan seni serta ilmu-ilmu sosial (humaniora) sebagai subyek utama pelajaran. Melalui konsep semacam ini, seminari

${ }^{33}$ Yohanes Bambang Mulyono, "Integritas Iman dan Tindakan," http://www.gki.or.id/doc.php?doctype, On Line 17 Nopember 2009

34 "Jemaat: Jangan Gagap Teologi," http://www.sabdaspace/jemaat_jangan_gagap_teologi, On Line 19 November 2009

35 Yohanes Bambang Mulyono, "Integritas Iman dan Tindakan," http://www.gki.or.id/doc.php?doctype, On Line 17 November 2009 
dari waktu ke waktu memusatkan dirinya pada kebenaran dan iman, kesalehan hidup, semangat akademik, dan mandat budaya dalam rangka memberi yang terbaik bagi gereja dan kerajaan Allah. ${ }^{36}$

Namun, dalam konteks kontemporer, pendidikan teologi lebih memilih berkonsentrasi pada mandat inti daripada mandat sekunder. Lebih lanjut Joseph Tong menjelaskan:

Pilihan ini mengakibatkan berkembangnya anggapan bahwa institusi dan pelajaran teologi mengajarkan hal yang tidak praktis, lebih banyak teori daripada kegunaan praktisnya bagi gereja. Akibatnya, gereja kemudian memandang para teolog sebagai ilmuwan tanpa keterampilan pastoral karena terpisah dari gereja. Teologi akhirnya tidak berakar ataupun berurat nadi. Mereka cenderung melihat para teolog dan mahasiswa teologi seperti pertapa dalam menara gading atau sebuah pulau terpencil di tengah lautan. Teologteolog akhirnya menjadi pengembara iman dan anak yang hilang dari gereja. ${ }^{37}$

Adaptabilitas praktis mutlak dimiliki seorang teolog, sehingga memudahkan teolog untuk memikirkan, merenungkan dan mengintegrasikan apa yang Alkitab nyatakan itu di dalam segala situasi kebudayaan dan kehidupan pada setiap zaman. ${ }^{38}$

Dengan demikian, adaptabilitas adalah kriteria khusus dalam menentukan kualitas seorang teolog, di mana seorang teolog harus mampu menyeimbangkan teori dan praktik, mengikuti pola inkarnasi di mana Kristus sebagai Tuhan yang menyatakan dirinya sebagai hamba sekaligus tuan; guru sekaligus murid.

\section{Motivasi (Motivation Oneself) dalam Doing Theology}

Salah satu prinsip kecerdasan emosi yaitu motivasi merupakan aspek penting bagi teolog dalam berteologi. Motivasi bukanlah tujuan, dan tujuan bukan motivasi. Motivasi adalah penyebab yang menghasilkan suatu tindakan, sedangkan tujuan adalah hasil yang diharapkan dapat tercapai melalui tindakan tersebut. ${ }^{39}$ Dalam konteks doing theology, motivasi dalam berteologi adalah Yesus Kristus, Sang Kebenaran sebagai motivasi utama dalam kegiatan intelektual orang percaya. Karena itu, setiap teolog harus menyambut kebenaran dan tunduk kepadanya di manapun itu ditemukan, dalam suatu sikap ketaatan kepada Kristus. ${ }^{40}$

${ }^{36}$ Joseph Tong, "Pentingnya Kualitas dalam Pendidikan Teologi," Jurnal Teologi Stulos vol 2 no 2 (Desember 2003), 66

${ }^{37}$ Ibid.

38 “Adaptabilitas," http://www.pesta.org/node/476, On Line 3 November 2009

${ }^{39}$ Stephen Tong, "Motivasi Memberitakan Injil" dalam Holistic Global Mission: Kepeloporan Petrus Oktavianus dalam Gerakan Misi Sedunia 2, (Batu: Literatur YPPII, 2007), 360

${ }^{40}$ Arthur F. Holmes, Segala Kebenaran adalah Kebenaran Allah, (Jakarta: Momentum, 2000), 208 
Seorang teolog yang memiliki motivasi murni (di dalam Kristus) tentunya akan memiliki komitmen dan loyalitas dalam memegang prinsipnya. Hal ini membuktikan bahwa motivasi murni dalam berteologi juga didasari oleh iman. W. Stanley Heath menjelaskan perihal komitmen:

Setiap pendeta dan dosen agama, bahkan setiap orang Kristen, harus mempunyai komitmen. Kalau tidak demikian ia cenderung menyesatkan, bukan menyelamatkan atau membangun. Dengan komitmen kita mengaku bahwa Roh Yesus lebih tahu dari pada kita sendiri apa yang perlu disampaikan dalam khotbah, pengajaran dan melalui konseling. Kata kuncinya penyerahan. Kita harus senantiasa mengabdi kepada kehendak Allah, sebagaimana kehendak itu dinyatakan dalam Alkitab dan dengan pengarahan ilahi yang khusus bagi kita sendiri melalui Roh Kudus. ${ }^{41}$

Hal ini sangat jelas untuk dimengerti, bahwa teolog dalam kehidupan berteologinya akan banyak menghadapi arus pemikiran teologi yang dinamis. Gerakan-gerakan baru, hasil interpretasi Alkitab yang variatif dan pengalamanpengalaman rohani orang lain, akan berpotensi membawa seorang teolog untuk bimbang dalam memegang prinsipnya. Karena itu, motivasi yang murni dapat mengatasi kecenderungan ketidakstabilan emosi seorang teolog.

\section{Empati (Empathy) dalam Doing Theology}

Sikap empati adalah suatu sikap yang benar-benar ikut merasakan penderitaan orang lain hingga menyebabkan ketidaknyamanan dengan kehidupan sendiri, karena melihat penderitaan orang lain. Sikap empati adalah suatu sikap yang melibatkan perasaan dari hati ke hati antara satu individu terhadap individu lain. ${ }^{42}$ Dalam hal ini Tuhan Yesus telah memberikan teladan ini dalam pelayanan-Nya, "Melihat orang banyak itu, tergeraklah hati Yesus oleh belas kasihan kepada mereka, karena mereka lelah dan terlantar seperti domba yang tidak bergembala" (Mat. 9: 36). Ironis sekali, jika seorang teolog yang memiliki pengetahuan dan pengalaman dengan Allah yang penuh kasih, namun tidak memiliki empati terhadap orang lain berupa pelayanan.

Karena itu, ilmu teologi tidak memberikan satu status pada teolog di dalam masyarakat selain status "pelayan." Semakin memiliki pengetahuan teologi yang banyak, seorang teolog semakin juga dituntut untuk melayani dan menjadi rendah hati, dan tidak dimaksudkan untuk membuat suatu elite akademis yang hanya

41 W. Stanley Heath, "Visi, Misi, Komitmen" dalam God's Fiery Challenger for Our Time, Benyamin F. Intan (Ed.), (Jakarta: STEMI, Reformed Center for Religion and Society, 2007), 413

${ }^{42}$ Dina M. Sinaga, "Renungan Matius 9:36," http://www.hkbp.or.id/index.php?news, On Line 19 November 2009 
membangun diri dengan ilmu yang bersifat esoteris. ${ }^{43}$ Berteologi yang benar adalah berteologi dalam arah memberitakan Injil. Teologi tidak hanya menuntun seorang teolog untuk mengenal Allah, tetapi juga untuk menjadi saksi agar orang-orang lain juga dapat mengenal-Nya di dalam Yesus Kristus. ${ }^{44}$

Pengertian seorang teolog tentang Allah serta rencana-Nya bagi seluruh dunia juga mempengaruhi pengertian seorang teolog tentang diri dan tujuan hidupnya di dunia ini. Dengan demikian, teolog yang berempati terhadap sesama khususnya orang-orang yang belum diselamatkan, tidak menjadi teolog yang sombong rohani yang mendirikan kembali menara Babel dalam teologinya.

\section{Keterampilan Sosial (Handling Relationship) dalam Doing Theology}

Dalam doing theology keterampilan sosial merupakan kompetensi interpersonal yang harus dimiliki oleh seorang teolog dalam kegiatannya berteologi. Berteologi yang benar tidak hanya menyentuh wilayah kognitif saja, karena hal tersebut hanya akan menjadikan teologi menjadi sesuatu yang eksklusif. Konteks berteologi adalah jemaat dan dunia. Karena itu, berteologi harus terbuka, inklusif, dan membangun jaringan dengan jemaat-jemaat dan dengan masyarakat. ${ }^{45}$

Teolog harus menaruh perhatiannya pada kemanusiaan sebagai keprihatinan teologi. Jadi, seorang teolog harus bisa berteologi secara kongkret, yaitu dalam suasana nyata. ${ }^{46}$ Dalam hal ini David Cupples menambahkan:

Firman Allah harus kita terapkan di segala segi kehidupan kita: pribadi, keluarga, gereja, masyarakat, bangsa dan lain-lain. Kehidupan masyarakat pun memiliki banyak segi: keamanan, negara, politik, ekonomi, lingkungan hidup, ideologi-ideologi yang bertentangan dan lain sebagainya. Dengan kata lain, kita dipanggil untuk mengembangkan suatu pandangan kristiani tentang dunia, dalam hidup kita secara pribadi dan secara bersama. Pengembangan ini menuntut banyak pelajaran dan pemikiran, dengan usaha yang berkesinambungan dan rohaniah. Usaha pengembangan ini merupakan buah yang dihasilkan oleh kepercayaan kita bahwa Yesus Kristus adalah Tuhan. Melalui usaha itu, kita mengaku Yesus Kristus sebagai Tuhan dalam segala segi

${ }^{43}$ Volkhard Scheunemann, Injil, Iman, dan Ilmu: Peranan Roh Kudus dan Rasio Dalam Hidup Manusia, Khususnya dalam Mengajar dan Belajar Ilmu Teologia, (Batu: Departemen Literatur YPPII, 1980), 22

${ }^{44}$ David Cupples, Beriman dan Berilmu: Spiritualitas Mahasiswa Teologi dan PAK, (Jakarta: BPK Gunung Mulia, 2007), 81

45 Jonathan Parapak, Pembelajar dan Pelayan, (Jakarta: Institut Darma Mahardika, 2002), 122

46 Daniels J. Adams, Teologi Lintas Budaya Refleksi Barat di Asia, (Jakata: BPK Gunung Mulia, 1992), xiii 
kehidupan kita, dan juga sebagai Tuhan bagi dunia. Dalam usaha itu, kita hendak memuliakan Dia serta berbakti kepada-Nya. ${ }^{47}$

Melihat kebutuhan yang signifikan ini, seorang teolog tidak bisa terlepas dari kemampuannya dalam berkomunikasi sebagai bagian dari kompetensi interpersonal. Hal ini penting bagi teolog yang memiliki tanggung jawab dalam menyampaikan kebenaran Allah dalam konteks tertentu. Karena itu, komunikasi yang inkarnatif dinilai penting dalam kaitannya dengan konteks penyampaian, seperti yang dijelaskan oleh Ronny Christian, bahwa:

Mengkomunikasikan kebenaran secara kontekstual tidak berarti kebenaran Allah tersebut bergantung pada konteks. Juga tidak berarti mensintesiskan atau menggabungkan kebenaran Allah dengan budaya atau nilai-nilai yang berlaku dalam konteks tersebut (Gal. 1:11-12; bnd Kis. 9). Akan tetapi, melalui cara yang kontekstual, kebenaran absolut tersebut dapat dikomunikasikan dengan efektif dan relevan dalam konteks komunikan. Komunikan dapat memahami dengan baik kebenaran yang disampaikan oleh komunikator dan pada akhirnya dapat mengurangi kesalahpahaman dalam berkomunikasi. Dengan demikian, dalam menyampaikan kebenaran tersebut harus menyadari dan mempertimbangkan konteks dari komunikan sehingga kebenaran yang disampaikan dapat dipahami oleh komunikan. ${ }^{48}$

Jadi, kompetensi interpersonal berupa komunikasi ini merupakan kebutuhan yang harus dimiliki oleh setiap teolog dalam merefleksikan pengetahuannya mengenai kebenaran Allah kepada dunia. Seorang teolog tidak hanya berkecimpung dalam lingkup akademis ataupun intelektualitas saja, yang hanya menghasilkan eksklusivisme, namun juga menyadari sebagai rekan sekerja Allah dalam pemberitaan Kabar Baik.

\section{B. Spiritual Quotient (SQ) dalam Doing Theology}

Ancaman bahaya, khususnya bagi teolog, ialah kecenderungan untuk memahami ilmu teologi sebatas hanya berkaitan dengan akal dan tidak dengan penghayatan iman. Berkenaan dengan hal itu, kecerdasan spiritual berperan penting dalam mewujudkan berteologi yang selaras dengan kebenaran Firman Allah. ${ }^{49}$

\footnotetext{
${ }^{47}$ David Cupples, Beriman..., 38

48 Ronny Christian, Urgensi Komunikasi Inkarnatif dalam Kepemimpinan Rohani Bagi Peningkatan Pelayanan Gembala Jemaat, (Tanjung Enim, Skripsi, 2005), 53

${ }^{49}$ Spiritualitas adalah nafas yang menghidupkan teologi, bukan hanya menjadi habits of head, tetapi utuh: habits of the heart, habits of the head, dan habits of the hands. Tanpa spiritualitas, teologi akan memfosil, akan menjadi kerangkeng, akan menjadi monumen, akan dijadikan ideologi dan -isme yang diberhalakan, akan dingin tanpa kehangatan kemanusiaan,akan hanya menyebut-nyebut Tuhan dalam berbagai dialog sengit tetapi hati tetap jauh dari Tuhan. Paul Hidayat, "Spiritual Formation
} 


\section{Iman (Faith) sebagai Dasar Doing Theology}

Sebagai dasar berteologi, iman yang benar mutlak untuk dimiliki oleh seorang teolog. Berteologi yang theosentris tentunya menjadikan Allah sebagai sumber imannya. Tanpa Allah dan Firman-Nya, tidak akan pernah ada iman. ${ }^{50}$ Dapat dikatakan bahwa teologi menggumuli dengan iman (kepercayaan yang pasti) akan apa yang dikatakan Alkitab mengenai Allah. ${ }^{51}$ Tidak patut disebut berteologi, apabila tidak memiliki iman kepada Allah sebagai subyek teologi atau sebagai penyingkap kebenaran-Nya kepada umat-Nya. ${ }^{52}$

Dalam tulisannya, Yonathan Wijaya Lo menjelaskan bahwa dalam tradisi teologi Reformasi, iman Kristen dimengerti meliputi tiga wilayah:

Pertama, pengetahuan. Pengetahuan adalah isi iman, dan tanpa pengetahuan maka iman Kristen itu sesuatu yang kosong. Iman Kristen berhubungan erat dengan pengertian, tapi tidak berarti pengetahuan mendahului iman melainkan sebaliknya. Pengertian yang benar tertumpu atas kebenaran Allah yang bersifat obyektif, dan absolut. Dalam hal ini, iman Kristen tidak perlu dikontraskan dengan rasio, sebab rasio yang benar tidak berdiri sendiri melainkan atas Firman Tuhan. Kedua, keyakinan. Iman Kristen bukan hanya unsur pengertian saja,melainkan juga keyakinan yang mendalam. Keyakinan tersebut bukan didasarkan oleh sesuatu yang bersifat subyektif melainkan oleh kebenaran absolut. Keyakinan ini bergema dalam hati dan berpijak kepada fondasi yang kuat yaitu Firman Allah. Ketiga, ketaatan. Ketaatan dan iman tidak bisa dipisahkan seperti Calvin mengatakan "to separate faith from trust would be equal to attempt to separate heat and light from the sun." Ketaatan mencakup seluruh aspek hidup yaitu terdiri rasio, kehendak, tindakan, sikap dan pikiran tunduk kepada Allah dan kebenaran-Nya. Ketaatan adalah natur iman Kristen sejati. ${ }^{53}$

Iman tidak mungkin mengambil jarak dan hanya membangun sikap kritis obyektif semata tanpa sikap partisipatif. Iman bukan saja penalaran atau aspek kognitif, tetapi melibatkan pula kemauan dan perasaan. ${ }^{54}$ Stephen Tong dalam hal ini memberikan tanggapan mengenai peranan rasio dalam iman, bahwa:

dalam Pendidikan Teologi” dalam Berteologi dalam Anugerah, Indriani Bone (Ed.), (Sidanglaya: STT Cipanas, 1997), 14

50 Joseph Tong, "Anatomi Kepercayaan dan Iman: Sebuah Refleksi Teologis dan Pastoral," http://reformed.sabda.org, On Line 6 November 2009

${ }^{51}$ Yakob Tomatala, Yesus Kristus Juruselamat Dunia: Satu-Satunya Jawaban Atas Masalah Manusia, (Jakarta: YT. Leadership Foundation, 2004), 19

${ }^{52}$ Stevri Indra Lumintang, Theologia..., 32

${ }^{53}$ Yonathan Wijaya Lo, "Iman Kristen dan Mandat Kebudayaan" dalam God's Fiery..., 354355

${ }^{54}$ Paul Hidayat, "Spiritual Formation dalam Pendidikan Teologi” dalam Berteologi..., 13 
Iman yang sejati bukan melawan rasio, tetapi mengembalikan fungsi rasio ke arah yang benar. Pada waktu kebenaran tidak menguasai otak, maka otak menjadi "anak terhilang." Tetapi pada waktu "anak terhilang" itu dibawa kembali kepada kebenaran dan tunduk setia kepada Tuhan dan kebenaran-Nya, itulah yang disebut iman. Maka iman tidak berlawanan atau di luar rasio. Iman justru arah yang benar untuk mengatur rasio kembali takluk kepada kebenaran. Roh Kudus bekerja melalui Firman dengan memberikan pencerahan kepada rasio kepada kita, sehingga kita dapat mengerti kebenaran. ${ }^{55}$

Iman selalu berkembang ketika Roh Allah bekerja dan manusia menanggapi secara kooperatif. Bahkan, keseluruhan kehidupan teolog, selain aspek akali atau keilmuan, juga harus memiliki landasan misterium tremendum (sikap takut akan Allah Sang Pribadi yang tak terselami). ${ }^{56}$

Secara sederhana, iman tidak dapat datang dari manusia, atau atas inisiatif manusia. Seperti yang dikemukakan oleh Paulus: "Iman timbul dari pendengaran, dan pendengaran oleh Firman Kristus. ...” (Rm. 10:17). Karena itu, secara teologis, iman itu murni pemberian Allah. Adalah Allah, yang dalam kemurahan-Nya, menyatakan Firman-Nya melalui wahyu, inkarnasi, pengilhaman dan penulisan Alkitab, dan penyataan. $^{57}$

Dapat dipastikan, seorang teolog yang memiliki kecerdasan spiritual berupa prinsip iman yang benar, adalah teolog yang akan memuliakan Allah dalam berteologi. Sebaliknya, teolog yang berteologi secara antroposentris, akan cenderung menilai Allah dengan ukuran manusia.

\section{Ritual sebagai Kekuatan Doing Theology}

Prinsip ritual (pengalaman rohani secara pribadi) adalah faktor yang menentukan perkembangan seorang teolog dalam pengenalannya terhadap Allah selain faktor rasio ataupun doktrin. Lebih lagi, tidak ada pengetahuan tentang Allah yang bersifat teoritis belaka, karena pengenalan tersebut melibatkan seluruh pengalaman pribadi seseorang, yaitu akal, hati nurani, dan kapasitas rohaninya. ${ }^{58}$ Bagi Calvin, pengalaman pribadi tidak berbenturan dengan rasio dan doktrin, melainkan justru meneguhkannya:

For [the doctrine of the gospel] is a doctrine not of the tongue but of life. It is not apprehended by the understanding and memory alone, as other disciplines

\footnotetext{
55 Stephen Tong, Dinamika Hidup dalam Pimpinan Roh Kudus, (Jakarta: Momentum, 1995), 56

${ }^{56}$ Paul Hidayat, "Spiritual Formation dalam Pendidikan Teologi”" dalam Berteologi..., 13

57 Joseph Tong, "Anatomi Kepercayaan dan Iman: Sebuah Refleksi Teologis dan Pastoral”, http://reformed.sabda.org, On Line 6 November 2009

${ }^{58}$ Paul Hidayat, "Spiritual Formation dalam Pendidikan Teologi” dalam Berteologi..., 12
} 
are, but it is received only when it possesses the whole soul, and finds a seat and resting place in the inmost affection of the heart. ${ }^{59}$

Calvin menempatkan pengalaman dalam kaitannya dengan keefektifan karya Roh Kudus sebagai interior magister yang beraspek ganda, yaitu iluminasi dan pemeteraian. Iman memiliki sisi pengertian (noetic) maupun afeksi (affective), sehingga iluminasi akal budi oleh Roh Kudus berjalan bersama dengan pekerjaan Roh Kudus di dalam hati. Sedangkan pemeteraian oleh Roh Kudus menjadikan otoritas Firman Allah pasti. ${ }^{60}$ Dalam hal ini, Athur F. Holmes juga menegaskan:

Pengalaman tentu saja penting dalam memperkaya kita, tetapi ia bukan hal yang terutama dalam kehidupan dan agama. Pengalaman dapat timbul dari hipnotis dan fantasi, pengalaman yang kelihatan rohani dapat dikarenakan oleh halusinogen. Apa yang paling menentukan bukan pengalaman tetapi kebenaran. Kebenaran mengenai Allah dan hubungan dengan-Nya jauh lebih penting dari perasaan yang muncul dari pengalaman agama. ${ }^{61}$

Di sisi lain, Marthin Luther menyatakan dengan sungguh-sungguh akan perlunya pengalaman yang benar serta kuasa Roh Kudus:

Tidak ada seorang pun yang dapat memahami Tuhan atau Firman-Nya jika ia tidak memperoleh pemahaman itu langsung dari Roh Kudus, dan juga pasti tak seorang pun dapat menerima pemahaman itu dari Roh Kudus kalau ia tidak mengalami, menguji dan merasakannya. Di dalam pengalaman demikian Roh Kudus mengajar kita . . . Pengalaman mutlak diperlukan untuk memahami Firman Allah bukan hanya untuk diulangi dan diketahui, tetapi juga untuk dihayati dan dirasakan. ${ }^{62}$

Dengan kata lain, pengalaman tidak dilihat sebagai milik khusus dalam diri manusia yang terlepas dari karya Roh Kudus yang membangkitkan iman, sehingga iman tidak boleh dimengerti hanya sebatas subyektif melainkan juga dimengerti dalam realita obyektif, yaitu Firman Allah. Beberapa kegiatan untuk memiliki pengalaman pribadi dengan Allah adalah doa, pembacaan Alkitab dan meditasi.

\section{a. Doa yang Jujur Kepada Allah}

Seorang teolog sebaiknya memiliki sikap seperti sikap pemazmur: "Singkapkanlah mataku supaya aku memandang keajaiban-keajaiban dari TauratMu" (Mzm. 119:18). Sangat menyedihkan bila mempelajari Alkitab secara akademis

${ }^{59}$ Billy Kristanto, "Kehidupan Kristen Menurut Calvin" dalam God's Fiery..., 342

${ }^{60}$ Willem Balke, "Revelation and Experience in Calvin's Theology" dalam Toward the Future of Reformed Theology-Taks, Topic, Tradition, David Willis and Michael Welker (Ed.), (Grand Rapids: Eerdmans, 2005), 359

${ }^{61}$ Arthur F. Holmes, Segala Kebenaran..., 137-138

${ }^{62}$ David Cupples, Beriman..., 71 
berakibat kepada ketidakpekaan terhadap hal-hal spiritualitas dari Alkitab. Penelitian kritis, suasana akademis dan tugas-tugas rutin, hanya menjadikan pikiran letih, perasaan tumpul dan kehausan akan Firman Tuhan berkurang.

Dalam keadaan demikian, seorang teolog perlu meminta kepada Tuhan agar Roh-Nya bekerja dalam dirinya, agar Alkitab menjadi Firman yang hidup dan melaluinya seorang teolog dapat mendengar suara Allah. ${ }^{63}$ Kebimbangan dan keraguan iman sering dialami seorang teolog, maka doa adalah tindakan yang tepat untuk meminta pertolongan-Nya. ${ }^{64}$ Dalam doa, keseluruhan hidup dibawa ke hadirat Allah, termasuk pengetahuan intelektual, di mana doa menjadi jembatan antara pemikiran kritis atau ilmiah dan spiritualitas. ${ }^{65}$ Lebih dari itu, dengan berdoa, Allah di dalam Yesus Kristus akan memberikan air hidup (Yoh. 4:10-14; 7:37-38), yang akan mengatasi kekeringan rohani seorang teolog.

\section{b. Pergaulan yang Teratur dengan Alkitab}

Dalam berteologi, kebenaran tidak hanya bersandar pada Allah semata, karena kebenaran juga bersandar pada wahyu tertulis yang Allah berikan kepada manusia, yaitu Alkitab. ${ }^{66}$ Dalam keyakinan Kristen, Alkitab dipakai Allah untuk berfirman kepada manusia, oleh karena itu dalam kecerdasan spiritualitas sangat diutamakan adanya kontak teratur dengan Alkitab. Pembacaan secara teratur berarti ada upaya terencana untuk membaca Alkitab pada saat-saat tertentu dan dengan program tertentu. ${ }^{67}$

Alkitab mengambil tempat utama dalam iman dan ibadah, oleh karena pengalaman rohani jika mengabaikan pembacaan Alkitab akan menghasilkan pengalaman rohani yang rapuh. ${ }^{68}$ Karena itu, perkembangan spiritualitas seorang teolog sangat bergantung pada pelajaran Alkitab dengan daya intelektual maupun daya rohani. Artinya, pembacaan Alkitab dalam suasana ibadah, juga dapat diteliti dengan teratur di dalam penelitian akademis. ${ }^{69}$ Dengan demikian, seorang teolog akan mencapai perkembangan pemahaman iman Kristen secara menyeluruh dan konsisten.

\section{c. Meditasi dalam Mencapai Kebersamaan dengan Allah}

${ }^{63}$ David Cupples, Beriman ..., 47

${ }^{64}$ Band. 1 Timotius 4:5

${ }^{65}$ B.F Drewes, Julianus Mojau, Apa Itu Teologi?: Pengantar ke Dalam Ilmu Teologi, (Jakarta: BPK Gunung Mulia, 2003), 31

${ }^{66}$ Joseph Tong, "Anatomi Kepercayaan dan Iman: Sebuah Refleksi Teologis dan Pastoral", http://reformed.sabda.org, On Line 6 November 2009

${ }^{67}$ B.F Drewes, Julianus Mojau, Apa Itu Teologi?..., 30

${ }^{68}$ David Cupples, Beriman..., 57

${ }^{69}$ Ibid, 40 
Tujuan utama ritual adalah persekutuan dengan Allah; menyembah dan memuji Dia, mengucap syukur kepada-Nya, mengaku dosa, mempersembahkan diri serta tidak kalah pentingnya merenungkan Firman-Nya dalam meditasi. ${ }^{70}$ Dalam pandangan umum praktik meditasi adalah doa. Mengenai hal ini, Victor Tinambunan menjelaskan:

Ada tiga jenis doa, yaitu: talking, listening, dan being (berbicara, mendengar dan berada). Berbicara: mengucapkan syukur atas kebaikan Tuhan; mengaku percaya akan kasih dan kebesaran Tuhan, menyampaikan permohonan kepada Tuhan dan sebagainya. Ini yang paling banyak dilakukan orang Kristen. Mendengar: mendengar sapaan Tuhan melalui pembacaan Firman-Nya (Alkitab), mendengar kehendak Tuhan melalui sesama manusia; melalui peristiwa nyata kehidupan sehari-hari. Berada: bersama dengan Tuhan. Yesus berkata, "Tinggallah di dalam Aku dan Aku di dalam kamu ..." (Yoh. 15:4). Meditasi adalah salah satu wahana untuk menghayati dan menerima undangan Yesus ini. Jadi, meditasi adalah bagian dari perjumpaan dengan Tuhan. ${ }^{71}$

Hakikatnya, meditasi bukanlah mengenai permohonan atau permintaan kepada Tuhan. Tetapi, yang terutama dalam meditasi adalah kebersamaan dengan Tuhan. Dalam meditasi yang diperlukan adalah sikap menyadari dan menyambut-Nya setiap saat, oleh karena yang dituntut dalam meditasi adalah keintiman dengan-Nya.

\section{Kelahiran Kembali (Born Again) sebagai Syarat Doing Theology}

Alkitab adalah karya Roh Kudus, dikarang oleh para nabi dan rasul yang diinspirasikan dan digerakkan oleh Roh Kudus (2Ptr. 1:21). Karena itu, Alkitab harus didekati di dalam roh, karena hal-hal yang rohani hanya dapat dinilai secara rohani (1Kor. 2:14). ${ }^{72}$

Karena itu, jika manusia hanya mengenal-Nya dalam otaknya, dan tidak dilahirkan kembali oleh Roh Kudus dalam rohnya, pengenalannya itu tidak akan dapat membantunya. Jika apa yang dipercayai manusia sebagai hikmat manusia, bukan kuasa Allah, itu hanya rangsangan dalam jiwa belaka, dan tidak bertahan lama, karena ia belum dilahirkan kembali. ${ }^{73}$

Tetapi di lain pihak, mengutamakan peranan Roh Kudus saja, juga akan menyebabkan penyimpangan. Dalam hal ini dibutuhkan keseimbangan antara Firman dan Roh, demikian yang dijelaskan oleh Stevri Indra Lumintang:

\footnotetext{
${ }^{70}$ Ibid, 46

71 "Meditasi dalam Literatur Kristen," http://victoralexanderliem.blogspot.com/2009/06/html,

72 Volkhard Scheunemann, Injil, Iman, dan Ilmu:..., 16

${ }^{73}$ Watchman Nee, Manusia..., 340
} On Line 6 November 2009 
Ketergantungan kepada Roh Kudus saja, akan memimpin kepada penyimpangan demi penyimpangan (aberrations) dan irasional (subjective theology) yang bermuara pada praktek mistis. Ketertutupan terhadap Roh Kudus juga akan menutup kemungkinan kepada tersembunyinya pengertian mengenai Firman atau kehendak Tuhan di dalam Alkitab. Roh Kudus menyebabkan seseorang beriman kepada Firman. Di sinilah letaknya kebesaran teologi dibandingkan dengan semua disiplin pengetahuan yang ada. Kombinasi Firman dan Roh Kudus mengungkapkan mengenai refleksi kritis dari pemikiran dan pengalaman kehadiran Tuhan secara pribadi melalui mempelajari Alkitab. Karena itu, seorang teolog dikatakan pantas berteologi, apabila ia mempelajari Alkitab dan memohon penyingkapan kebenaran Alkitab dari Roh Kudus. Itu berarti, tidak ada teologi tanpa Alkitab dan peranan Roh Kudus. ${ }^{74}$

Dengan demikian, kelahiran baru dalam roh merupakan syarat mutlak bagi seorang teolog dalam pendekatan terhadap Alkitab, oleh karena hanya Roh Kudus yang menyaksikan mengenai Yesus Kristus dan memimpin teolog ke dalam kebenaran Injil. Di sinilah prinsip kecerdasan spiritual yaitu kelahiran baru, yang harus dimiliki oleh setiap teolog yang ingin mempelajari Alkitab.

\section{Kasih Kepada Allah sebagai Kunci Doing Theology}

Kasih membuka jalan untuk mengerti rahasia-rahasia Allah (1Kor. 2:9), oleh karena kebenaran adalah satu Pribadi (Yoh. 14:6), maka hanya teolog yang mengasihi Allah akan mengenal kebenaran, dan ia "dikenal" oleh Allah (1Kor. 8:3; Gal. 4:9). Kasih sendiri adalah batu ujian bagi pengetahuan yang benar. Pengetahuan yang tidak didasari dengan sikap takut akan Tuhan, dengan sendirinya akan membuat teolog menjadi sombong, oleh karena hanya kasih yang dapat membangun (1Kor. 8:1) dan menjadikan orang yang berpengetahuan sedia mengabdi. ${ }^{75}$

Jadi, dengan memiliki prinsip ini, seorang teolog akan menemukan kebenaran Allah yang sejati, "Apa yang tidak pernah dilihat oleh mata, dan tidak pernah didengar oleh telinga, dan yang tidak pernah timbul di dalam hati manusia: semua itu disediakan Allah untuk mereka, yang mengasihi Dia.” (1Kor. 2:9).

\section{Persatuan dengan Kristus (Union With Christ) sebagai Sentral Doing Theology}

Yesus Kristus adalah sentral Alkitab. Sebagaimana oleh darah-Nya Ia telah membuka suatu "jalan yang baru dan yang hidup" ke dalam tempat kudus melalui tabir (Ibr. 10:19-20) yang "terbelah dua dari atas sampai ke bawah" pada jam

\footnotetext{
${ }^{74}$ Stevri Indra Lumintang, Theologia..., 74-75

${ }^{75}$ Volkhard Scheunemann, Injil, Iman, dan Ilmu:..., 24
} 
kematian-Nya (Mat. 27-51), demikian juga Yesus membuka satu jalan yang baru dan hidup untuk masuk ke dalam Alkitab dengan membuka tabir dan mengambil "selubung" yang menahan manusia untuk melihat kemuliaan Alkitab (2Kor. 3:1416). ${ }^{76}$

Selain itu Yesus Kristus adalah pusat Alkitab. Segala sesuatu yang ditulis sebelum kedatangan-Nya menunjuk kepada Dia, dan segala sesuatu yang ditulis sesudahnya menjelaskan maksud kedatangan dan karya keselamatan-Nya. Hanya dari pusat itulah Alkitab sebagai sumber teologi dapat dimengerti dan diartikan. ${ }^{77}$ Singkatnya, tujuan Alkitab satu-satunya ialah agar teolog dapat mengenal Allah dan Anak-Nya Yesus Kristus dengan pengenalan sejati yang mendatangkan hidup yang kekal (Yoh. 17:3). ${ }^{78}$

Yesus Kristus adalah satu-satunya jalan menuju pertumbuhan rohani, yaitu dalam kepenuhan di dalam Yesus Kristus, karena "Seluruh kepenuhan Allah berkenan diam di dalam Dia" (Kol. 1:15-19). ${ }^{79}$ Itu berarti, spiritualitas tidak mungkin terjadi di luar persekutuan iman dalam Yesus Kristus dan tidak lepas dari perspektif kebenaran yang dikisahkan dalam Alkitab. ${ }^{80}$

Dengan demikian, memiliki persatuan dengan Kristus yang hidup, Sang Juruselamat, maka iman percaya membuat seorang tidak hanya rela mati bagi apa yang diyakininya, tetapi juga membuatnya mampu untuk terus menjalani apa yang diyakininya dalam kehidupan. Seperti yang Paulus serukan, "Karena bagiku hidup adalah Kristus . . ." dan “. . . hidupku yang kuhidupi sekarang di dalam daging, adalah hidup oleh iman dalam Anak Allah yang telah mengasihi aku dan menyerahkan diri-Nya untuk aku." (Flp. 1:21; Gal. 2:20).

\section{Kesimpulan}

Doing theology yang benar adalah kegiatan berteologi yang subyek utama dan dasar pelajaran teologi terletak pada wahyu Allah bukan pada yang lain. Wahyu Allah secara konkrit diberikan dalam Alkitab, dan inti keselamatan dijelaskan hanya ada dalam pribadi Yesus Kristus. Tetapi dalam praktiknya, banyak para teolog yang tidak konsisten dalam prinsip tersebut, sehingga menghasilkan teologi-teologi yang justru menjauh dari kebenaran. Hasilnya, hilangnya esensi dari orthodoxi, orthopathi dan orthopraxi dalam berteologi.

\footnotetext{
76 Ibid, 15

77 Volkhard Scheunemann, Injil, Iman, dan Ilmu:..., 15

${ }^{78}$ David Cupples, Beriman..., 25

${ }^{79}$ Hans Maris, Gerakan Karismatik dan Gereja Kita, (Jakarta: Momentum, 2004), 33

${ }^{80}$ Paul Hidayat, "Spiritual Formation dalam Pendidikan Teologi" dalam Berteologi..., 15
} 
Di sinilah peranan Emotional Spiritual Quotient (ESQ) dalam berteologi. Emosi dan spiritual yang cerdas memiliki peranan besar dalam berteologi, selain cerdas secara intelektual. Kecerdasan emosi yang terdiri dari kompetensi intrapersonal dinilai memberikan kontribusi dalam memanage dan mengontrol emosi (perasaan) dalam meresponi penyataan Allah, dan kompetensi interpersonal dalam hal ini adalah tanggung jawab teolog dengan relasi sosialnya. Begitu juga dengan kecerdasan spiritual yang adalah sentral dari semua kecerdasan. Relasi dengan Allah sebagai sumber teologi, pokok teologi serta tujuan teologi akan menentukan arah dan tujuan kegiatan berteologi, oleh karena hanya teolog yang memiliki hubungan yang intim dengan Allah yang akan dibukakan kebenaran-kebenaran akan diri-Nya dan menghasilkan doxologi (puji-pujian) kepada Allah.

\section{KEPUSTAKAAN}

1995 Webster's II New College Dictionary, (Boston/New York: Houghton Mifflin Company, 1995), s.v. "emosi"

Agustian, Ary Ginanjar

2005 Rahasia Sukses Membangun Kecerdasan Emosi dan Spiritual (ESQ) Emotional Spiritual Quotient Berdasarkan 6 Rukun Iman dan 5 Rukun Islam,Jakarta: Penerbit Arga

Balke, Willem

2005 "Revelation and Experience in Calvin's Theology" dalam Toward the Future of Reformed Theology-Taks, Topic, Tradition, David Willis and Michael Welker (Ed.), Grand Rapids: Eerdmans

Billy, Dennis J. James F. Keating

2008 Suara Hati dan Doa: Belajar Terbuka pada Kebenaran, Yogyakarta: Kanisius

Christian, Ronny

2005 Urgensi Komunikasi Inkarnatif dalam Kepemimpinan Rohani Bagi Peningkatan Pelayanan Gembala Jemaat, Tanjung Enim, Skripsi

Cupples, David

2007 Beriman dan Berilmu: Spiritualitas Mahasiswa Teologi dan PAK, Jakarta: BPK Gunung Mulia

Drewes, B.F Julianus Mojau,

2003 Apa Itu Teologi?: Pengantar ke Dalam Ilmu Teologi, Jakarta: BPK Gunung Mulia

Enklaar, H. Berkhof, I.H.

1999 Sejarah Gereja, Jakarta: BPK Gunung Mulia 
Gunawan, Hendra

2006 "Gereja, Teologi, dan Pertumbuhan Rohani," Jurnal Amanat Agung vol 2 no 1, April

Hidayat, Paul

1997 "Spiritual Formation dalam Pendidikan Teologi" dalam Berteologi dalam Anugerah, Indriani Bone (Ed.), Sidanglaya: STT Cipanas

Holmes, Arthur F.

2000 Segala Kebenaran adalah Kebenaran Allah, Jakarta: Momentum

Jonge, Christian de 1993 Pembimbing ke Dalam Sejarah Gereja, Jakarta: BPK Gunung Mulia,

Lumintang, Stevri Indra

2006 Theologia dan Misiologia Reformed, Batu: Departemen Literatur PPII,

Maris, Hans

2004 Gerakan Karismatik dan Gereja Kita, Jakarta: Momentum

Meyer, Joyce

2005 Mengelola Emosi Anda, Batam: Gospel Press

Nee, Watchman

1999 Manusia Rohani 2, Surabaya: Yayasan Perpustakaan Injil Indonesia

Parapak, Jonathan

2002 Pembelajar dan Pelayan, Jakarta: Institut Darma Mahardika

Roberts, Roger

2000 Hidup Suci: Panggilan Bagi Setiap Orang Kristen, Bandung:

Lembaga Literatur Baptis

Samuel, Wilfred J.

2007 Kristen Kharismatik, Jakarta: BPK Gunung Mulia

Scheunemann, Volkhard

1980 Injil, Iman, dan Ilmu: Peranan Roh Kudus dan Rasio Dalam Hidup

Manusia, Khususnya dalam Mengajar dan Belajar Ilmu Teologia, Batu: Departemen Literatur YPPII

Singgih, E. Gerrit

2005 Mengantisipasi Masa Depan: Berteologi dalam Konteks di Awal Milenium III, Jakarta: BPK Gunung Mulia

Sproul, R.C.

2001 Mengenali Alkitab, Malang: Literatur SAAT

Stanley Heath, W.

2007 "Visi, Misi, Komitmen" dalam God's Fiery Challenger for Our Time, Benyamin F. Intan (Ed.), Jakarta: STEMI, Reformed Center for Religion and Society

Tomatala, Yakob

2004 Yesus Kristus Juruselamat Dunia: Satu-Satunya Jawaban Atas Masalah Manusia, Jakarta: YT. Leadership Foundation

Tong, Joseph 
2003 "Pentingnya Kualitas dalam Pendidikan Teologi," Jurnal Teologi Stulos vol 2 no 2 Desember

Tong, Stephen

2007 "Motivasi Memberitakan Injil" dalam Holistic Global Mission:

Kepeloporan Petrus Oktavianus dalam Gerakan Misi Sedunia 2, Batu: Literatur YPPII

Tong, Stephen

1995 Dinamika Hidup dalam Pimpinan Roh Kudus, Jakarta: Momentum,

1997 Roh Kudus, Suara Hati Nurani dan Setan, Jakarta: Momentum

Wilfred J. Samuel

2007 Kristen Kharismatik: Refleksi atas Berbagai Kecenderungan Pasca Kharismatik, Jakarta: BPK Gunung Mulia

Wongso, Peter

2002 Hamba Tuhan dan Jemaat Kristus yang Melintasi Zaman, Malang:

Literatur SAAT

Adams, Daniels J.

1992 Teologi Lintas Budaya Refleksi Barat di Asia, Jakata: BPK Gunung Mulia

Andreas, Andi

"Menjaga Integritas," http://www.akupercaya.com/forums/pengajaranalkitab/6372- html, On Line 17 November 2009

Mulyono, Yohanes Bambang

"Integritas Iman dan Tindakan," http://www.gki.or.id/doc.php?doctype, On

Line 17 Nopember 2009

Tong, Joseph

"Anatomi Kepercayaan dan Iman: Sebuah Refleksi Teologis dan Pastoral," http://reformed.sabda.org, On Line 6 November 2009

Wijongko, Martin

"Integritas: Menepati Komitmen," http://www.smakristencilacap.com, On Line 17 November 2009 